\title{
Kinetics of lactose crystallization and crystal size as monitored by refractometry and laser light scattering: effect of proteins
}

\author{
Arnaud MIMOUNI ${ }^{\mathrm{a}, \mathrm{b}}$, Pierre SCHUCK ${ }^{\mathrm{a} *}$, Saïd BOUHALLAB ${ }^{\mathrm{a}}$ \\ a UMR 1253 Science et Technologie du Lait et de l'CEuf, Inra-Agrocampus Rennes, \\ 65 rue de Saint-Brieuc, 35042 Rennes Cedex, France \\ b EUROSERUM, Route de Luxeuil, 70170 Port-sur-Saône, France
}

Published online 14 June 2005

\begin{abstract}
Lactose crystallization is a key step in the manufacture of whey powders. Both the crystal size and mass of crystals produced affect the subsequent step of spray drying and whey powder quality. Consequently, it is essential to control crystallization kinetics, crystal quality and how these properties are affected by whey components. For this purpose, two suitable and simple methods were developed. Refractometry was used to follow the kinetics of lactose crystallization in supersaturated solution of lactose. The extent of crystallization and the overall crystallization rate constant were then deduced. Laser light scattering was used to follow the crystal growth in the solid phase by measuring crystal size over time. The two methods were used to determine the impact of whey proteins on lactose crystallization from supersaturated solution. Our first results showed that the presence of whey proteins $\left(5 \mathrm{~g} \cdot 100 \mathrm{~g}^{-1}\right.$ water $)$ did not significantly modify the overall crystallization rate constant but had a large lowering effect on the final size of crystals during the non-seeded crystallization process ( $30 \mu \mathrm{m}$ against $\sim 105 \mu \mathrm{m}$ in the absence of protein).
\end{abstract}

lactose crystallization / whey proteins / refractometry / laser light scattering

Résumé - Cinétique de cristallisation du lactose et taille des cristaux mesurées par réfractométrie et granulométrie laser: influence des protéines. L'étape de cristallisation du lactose est une étape clé de la fabrication des poudres de lactosérum. La taille et la masse des cristaux de lactose produits sont des caractéristiques qui affectent l'étape ultérieure de séchage par atomisation ainsi que les qualités physico-chimiques des poudres. En conséquence, il est essentiel de maîtriser la cinétique de cristallisation ainsi que la qualité des cristaux, et de comprendre comment ces propriétés sont affectées par les divers constituants des lactosérums. Dans ce travail, nous avons développé deux méthodes simples permettant de suivre la cinétique de cristallisation en mode discontinu et l'évolution de la taille des cristaux. La réfractométrie est utilisée pour suivre l'étape de cristallisation par la mesure des variations de la concentration en lactose restant en solution pendant la cristallisation d'une solution sursaturée. Une constante de vitesse globale de cristallisation a été déduite. La granulométrie laser est utilisée pour suivre l'évolution de la cristallisation dans la phase solide en mesurant la taille des cristaux au cours du temps. Ces deux méthodes ont été appliquées pour déterminer l'impact des protéines sériques $\left(5 \mathrm{~g} \cdot 100 \mathrm{~g}^{-1} \mathrm{H}_{2} \mathrm{O}\right)$ sur la cristallisation du lactose en solution sursaturée. Les résultats montrent que la présence de protéines ne modifie pas significativement la constante de vitesse globale de la cristallisation mais entraîne une baisse sensible de la taille finale des cristaux à l'issue d'une cristallisation non ensemencée ( $\sim 30 \mu \mathrm{m}$ contre $\sim 105 \mu \mathrm{m}$ en l'absence de protéines).

cristallisation du lactose / protéines du lactosérum / réfractométrie / granulométrie laser

\footnotetext{
* Corresponding author: pierre.schuck@ rennes.inra.fr
} 


\section{INTRODUCTION}

Spray drying is a key step in the manufacture of food products and ingredients. Although conventional milk powder dehydration is quite well known on an industrial scale, development of new products produced from qualitatively different whey sources, causes a number of problems concerning drying and conservation, mainly due to amorphous lactose. A previous step of lactose crystallization in concentrated whey is thus necessary. It is essential to control this step in order to obtain specified and reproducible powders, in terms of size and crystallization level, whatever the initial chemical composition. The objective of our work is to understand the mechanisms determining lactose phase transition and crystal growth kinetics in a complex and variable environment of minerals and proteins. As part of this large study, we present here the applications of simple methods for rapid estimation of crystal growth kinetics. A number of techniques have been related to monitor lactose crystallization [6]. Among the most recent research, lactose concentration in the liquid phase was measured by the enzymatic method [12], refractometry $[4,7]$ or indirectly by weighing crystals formed over time $[2,9]$. Additionally, the shape and size of lactose in the solid phase was examined by optical microscopy [4], polarized light microscopy and image analysis [1], scanning electron microscopy [9], electrozone particle counting [11] and laser light scattering at the final stage [9]. Several strategies were also performed to evaluate growth parameters of lactose crystals: single crystal growth at constant supersaturation $[1,2]$ or the MSMPR (mixed suspension mixed product removal) approach [11]. In the present work, we applied two methods to follow in real time and simultaneously the course of the whole batch crystallization over time, both in the liquid phase, by measuring changes in lactose dissolved concentration using refractometry, and in the solid phase, analyzing evolution of CSD (crystal size distribution) by laser light scattering. The effect of proteins on these two crystallization properties was also studied.

\section{MATERIALS AND METHODS}

\subsection{Crystallization procedure}

Supersaturated aqueous solutions of lactose were prepared from $\alpha$-lactose monohydrate powder (pharmaceutical grade, Lactoserum France, Verdun, France) by dissolution in distilled water, ensured through occasional shaking and heating at $\sim 90{ }^{\circ} \mathrm{C}$ for a few seconds, in a closed vessel to prevent evaporation of the solvent. The solution was then rapidly cooled down to crystallization temperature $\left(30{ }^{\circ} \mathrm{C}\right)$ at which it was maintained, without stirring, for $2 \mathrm{~h}$ to ensure that mutarotation equilibrium was achieved [9]. The solution was then rapidly filtered under vacuum. In the case of crystallization of lactose from supersaturated solutions containing whey proteins, a solution of proteins was prepared beforehand by reconstitution of a whey protein concentrate (Armor Protéines, Saint Brice en Cogles, France) in distilled water. The solution was stirred for several hours at $25{ }^{\circ} \mathrm{C}$ and was incorporated into the cooled lactose solution so as to avoid heat-induced gelification, the final solution containing whey protein at $5.0 \mathrm{~g} \cdot 100 \mathrm{~g}^{-1}$ water. Crystallization was carried out in a $400-\mathrm{mL}$ vessel (diameter $=77 \mathrm{~mm})$ maintained at crystallization temperature using a water bath. The supersaturated solution was stirred in order to obtain good heat transfer and homogeneity and to reduce the induction time. Stirring was undertaken by magnetic stirring, and started at time $t=0$. The stirring rate was fixed at $500 \pm 100 \mathrm{rpm}$ in all experiments. When seeded crystallization runs were carried out, seeding was ensured at $t=0$ by adding $100 \mathrm{mg}$ of $\alpha$-lactose monohydrate powder to the supersaturated solution. Seeding was performed in order to reduce induction time and hence to calculate the crystallization rate constant from $t=0$. All the experiments were performed in triplicate.

\subsection{Measurement of dissolved lactose concentration}

Sampling was performed by extraction of a volume of $1 \mathrm{~mL}$ from the crystal suspension 
and centrifugation at $2000 \times g$ for $10 \mathrm{~s}$. An Atago refractometer was used to measure the refractive index of the supernatant. The elimination of the crystals from the sample made measurement easier and more precise. A calibration curve was performed in order to convert the refractive index of the solution (expressed in ${ }^{\circ}$ Brix units) into lactose concentration expressed as $\mathrm{g} \cdot 100 \mathrm{~g}^{-1}$ water or as $\mathrm{g} \cdot 100 \mathrm{~g}^{-1}$ solution. For this purpose, solutions of known lactose concentration $\left(\right.$ at $\left.30^{\circ} \mathrm{C}\right)$ were used.

\subsection{Particle size analysis}

Crystal size analysis was carried out using a Malvern Master Sizer 2000 (Malvern, Worcestershire, UK). Representative samples of crystal suspension (volume $\sim 1 \mathrm{~mL}$ ) were introduced into the dispersant medium of the laser light scattering particle analyzer at different times during the crystallization process. The samples of crystal suspension passed through the path of a laser beam where each particle diffracted the light. The diffraction pattern was measured by detectors disposed in the form of concentric circles. Crystal size was calculated based on the angle and the intensity detected. A volume relative distribution, which is equivalent to the mass particle relative distribution if the crystal density is constant, was generated directly. The volume relative distribution represents the volume, versus crystal size, of each class of crystals expressed as fraction of total volume. Analyzer software parameters appropriate for crystal analysis were selected for calculation of size distribution: "general purpose", "normal calculation sensitivity" and "irregular particle shape". A refractive index of 1.53 for $\alpha$-lactose monohydrate crystals, as determined by Bushill et al., was used [3]. A slightly supersaturated lactose solution at $25^{\circ} \mathrm{C}\left(27.5 \mathrm{~g} \cdot 100 \mathrm{~g}^{-1}\right.$ water $)$ was prepared as mentioned above and was used as dispersant medium to prevent the dissolution of crystals in the analyzer. The refractive index of the dispersant medium was determined by refractometry and taken into account in the calculation model.



Figure 1. Refractive Index ( ${ }^{\circ}$ Brix units) as a function of lactose concentration expressed either as $\mathrm{g} \cdot 100 \mathrm{~g}^{-1}$ water $(\square, \boldsymbol{\square})$ or as $\mathrm{g} \cdot 100 \mathrm{~g}^{-1}$ solution $(\triangle, \mathbf{A})$. Experimental data in pure solution of lactose $(\mathbf{\square}, \mathbf{\Delta})$ and in a solution of lactose containing whey protein at $5 \mathrm{~g} \cdot 100 \mathrm{~g}^{-1}$ water $(\square, \triangle)$. The calibration curves represent the best linear and hyperbolic fit of experimental data.

\section{RESULTS AND DISCUSSION}

\subsection{Measurement of dissolved lactose concentration}

Refractometry was described as a suitable method for the quantitative determination of lactose dissolved in dairy products, and specifically in concentrated whey [10]. This method relies on the fact that the refractive index of a multicomponent dissolved system is a function of the concentration of solutes. The effect on the refractive index of the presence of other components in the lactose solution being unknown, a calibration curve has to be constructed for each mixture. Figure 1 shows the calibration curves of two different solutions: a pure solution of lactose and a solution of lactose containing whey protein at $5 \mathrm{~g} \cdot 100 \mathrm{~g}^{-1}$ water. The results show that, as in the case of a sucrose solution, the refractive index expressed in the ${ }^{\circ}$ Brix unit of a solution of lactose is a linear function of lactose concentration when the concentration was expressed as $\mathrm{g} \cdot 100 \mathrm{~g}^{-1}$ water of solution. The presence of proteins increases the refractive index of the solution, resulting in 




Figure 2. Desupersaturation curve ( $\square$ ) and extent of crystallization (ם). Typical graph of experimental data of seeded lactose crystallization from pure supersaturated solution at $30^{\circ} \mathrm{C}$ (initial lactose concentration of $70 \mathrm{~g} \cdot 100 \mathrm{~g}^{-1}$ water). a higher value of the intercept of the calibration line. For lactose solutions containing whey protein at $5 \mathrm{~g} \cdot 100 \mathrm{~g}^{-1}$ water, the intercept increased by $6.3{ }^{\circ}$ Brix units. When expressed in $\mathrm{g} \cdot 100 \mathrm{~g}^{-1}$ water, lactose concentration is not a linear function of the refractive index, which is explained by the hyperbolic relationship between concentrations expressed as $\mathrm{g} \cdot 100 \mathrm{~g}^{-1}$ solution and as $\mathrm{g} \cdot 100 \mathrm{~g}^{-1}$ water.

\subsection{Desupersaturation curve}

Using the calibration curve above, the crystallization step was monitored from a supersaturated solution of lactose (i.e. initial lactose concentration of $70 \mathrm{~g} \cdot 100 \mathrm{~g}^{-1}$ water) at $30{ }^{\circ} \mathrm{C}$ (Fig. 2). The so-called desupersaturation curve is obtained by plotting the lactose remaining in solution over time, during isothermal batch crystallization [5, 12]. This curve results from the overall process of lactose crystallization, including the following different steps: lactose $\alpha-\beta$ mutarotation, solute transfer through the bulk solution to the crystal interface and incorporation of growth units into the crystal lattice $[6,12]$. Nevertheless, it has been stated that mutarotation reaction is not a limiting factor [9].

\subsection{Calculation of crystal mass evolution from desupersaturation curve}

A mass balance of lactose (Eq. 1) and water (Eq. 2) between $t=0$ and $t$ enables us to calculate the crystal mass obtained at time $t$ (Eq. 3), assuming that water represents $5 \%$ of total mass of $\alpha$-lactose monohydrate crystal.

$$
\begin{aligned}
& \frac{C(0)}{100} \cdot M_{\mathrm{H}_{2} \mathrm{O}}(0)=\frac{C(t)}{100} \cdot M_{\mathrm{H}_{2} \mathrm{O}}(t)+0.95 \cdot M_{\text {Crystal }}(t) \\
& M_{\mathrm{H}_{2} \mathrm{O}}(0)=M_{\mathrm{H}_{2} \mathrm{O}}(t)+0.05 \cdot M_{\text {Crystal }}(t)
\end{aligned}
$$

$M_{\text {Crystal }}(t)=M_{\mathrm{H}_{2} \mathrm{O}}(0) \cdot \frac{C(0)-C(t)}{95-0.05 \cdot C(t)}$

with $C$ being the dissolved lactose concentration expressed as $\mathrm{g} \cdot 100 \mathrm{~g}^{-1}$ water and $\mathrm{M}_{\mathrm{H}_{2} \mathrm{O}}$ and $M_{\text {Crystal }}$, respectively, the mass of water and crystals, both expressed as $\mathrm{g}$.

The extent of crystallization defined by equation 4 can also be calculated, taking into account the lactose solubility value $C(t \rightarrow \infty)$ at $30^{\circ} \mathrm{C}$.

$$
\begin{gathered}
Y(t)=\frac{M_{\text {Crystal }}(t)}{M_{\text {Crystal }}(t \rightarrow \infty)} \\
Y(t)=\frac{C(0)-C(t)}{95-0.05 \cdot C(t)} \cdot \frac{95-0.05 \cdot C(t \rightarrow \infty)}{C(0)-C(t \rightarrow \infty)}
\end{gathered}
$$

An example of the evolution of the extent of lactose crystallization from seeded supersaturated solution is shown in Figure 2. In this case, $80 \%$ of the mass of crystals is formed 


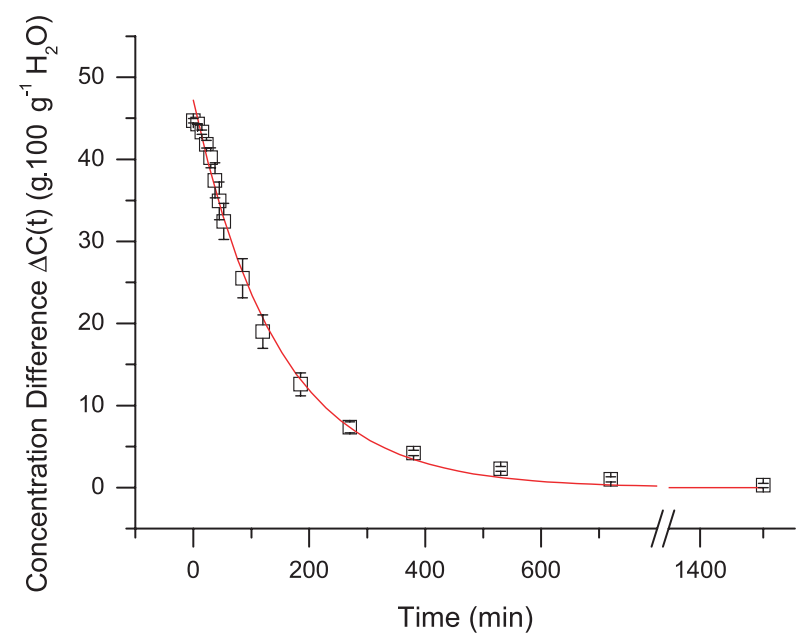

Figure 3. Concentration difference versus time. Typical graph of experimental data of seeded lactose crystallization from pure supersaturated solution at $30{ }^{\circ} \mathrm{C}(\square)$ (initial lactose concentration of $70 \mathrm{~g} \cdot 100 \mathrm{~g}^{-1}$ water). The curve represents the best first-order exponential decay fit.

after $200 \mathrm{~min}, 90 \%$ after $300 \mathrm{~min}$ and $100 \%$ after $\sim 1500 \mathrm{~min}$. Refractometry is hence a suitable technique to calculate crystal mass throughout crystallization until the end of the process. In contrast, other methodologies, such as digital microscopy, lose their sensitiveness at extended crystallization times when overlapping of crystals occurs [1]. Refractometry also avoids difficulties involved in relating individual linear crystal surface growth to crystal mass growth [12]. Another advantage of this technique is that it can be easily implemented whatever the design of the crystallizer.

\subsection{Desupersaturation curve data analysis}

Assuming that the mutarotation rate was much faster than crystallization [9], and assuming that conversion of lactose in solution into crystallized lactose was a single step, first-order, non-reversible reaction, treatment of the desupersaturation curve can be simplified as :

$$
\text { Dissolved } \alpha \text {-Lactose } \underset{\mathrm{a}}{\stackrel{k}{\longrightarrow}}
$$

Crystallized $\alpha$-Lactose Monohydrate

$k$ : overall lactose crystallization rate constant.

After integration of equation 7 , the return to thermodynamic equilibrium is described by a first-order exponential decay equation (Eq. 8):

$$
\begin{aligned}
-\frac{d C(t)}{d t} & =k \cdot[C(t)-C(t \rightarrow \infty)] \\
\Delta C(t) & =\Delta C(0) \cdot \exp (-k \cdot t)
\end{aligned}
$$

where the concentration difference is $\Delta C(t)=\mathrm{C}(\mathrm{t})-C(t \rightarrow \infty)$, with $C(t)$ and $C(t \rightarrow \infty)$, the dissolved lactose concentrations, respectively, at time $t$ and at thermodynamic equilibrium at the temperature of interest (i.e. solubility value), both expressed as $\mathrm{g} \cdot 100 \mathrm{~g}^{-1}$ water.

The fitting of the experimental curve $\Delta C=f(t)$ with a first-order exponential decay function, using a non-linear regression performed by Origin 6.1 (OriginLab Corporation, Northampton, MA 01060 USA) (Fig. 3), gives the $k$ values reported in Table I.

Desupersaturation curves were obtained from crystallization of seeded lactose supersaturated solutions (initial lactose concentrations of 60,70 and $80 \mathrm{~g} \cdot 100 \mathrm{~g}^{-1}$ water) with and without whey proteins $\left(5 \mathrm{~g} \cdot 100 \mathrm{~g}^{-1}\right.$ water) at $\mathrm{T}=30^{\circ} \mathrm{C}$. Data analysis using a single step, first-order reaction treatment was successfully performed in both cases (regression correlation coefficient >0.99) (Tab. I). Seeding with an amount of $100 \mathrm{mg} \alpha$-lactose monohydrate powder had no significant effect on the $k$ value, and neither did the initial lactose 


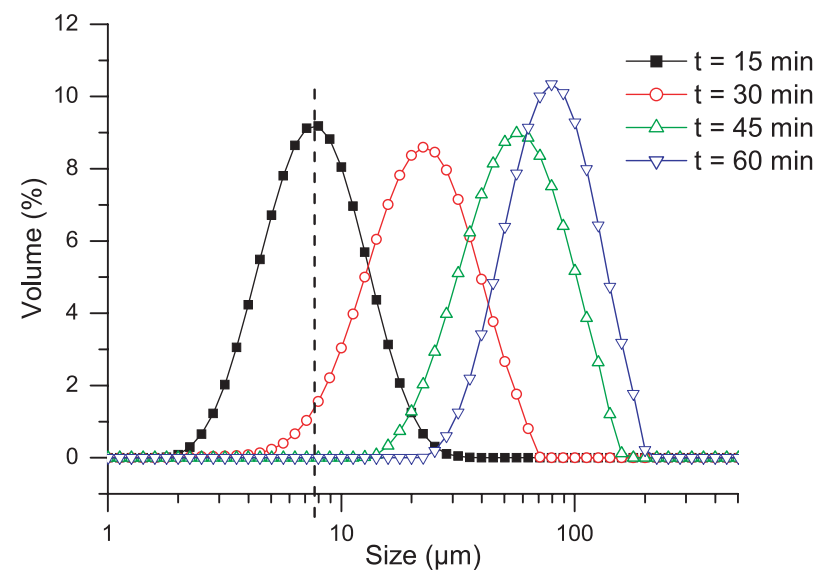

Figure 4. Crystal size distributions at different times during non-seeded lactose crystallization from pure supersaturated solution at $30^{\circ} \mathrm{C}$ (initial lactose concentration of $70 \mathrm{~g} \cdot 100 \mathrm{~g}^{-1}$ water).

Table I. Overall lactose crystallization rate constant, $k\left(10^{-3} \cdot \mathrm{min}^{-1}\right)$, and regression correlation coefficient $R^{2}$ (first-order exponential decay fit) for different experiments of crystallization of lactose supersaturated solution with and without whey protein $\left(5 \mathrm{~g} \cdot 100 \mathrm{~g} \mathrm{~g}^{-1}\right.$ water) at $30{ }^{\circ} \mathrm{C}$. The values are given \pm standard deviation.

\begin{tabular}{|c|c|c|c|}
\hline $\begin{array}{l}\text { Whey Protein Concentration } \\
\qquad\left(\mathrm{g} \cdot 100 \mathrm{~g}^{-1} \mathrm{H}_{2} \mathrm{O}\right)\end{array}$ & Number of replicates & Mean $R^{2}$ & $\begin{array}{l}\text { Mean Rate Constant } k \\
\left(10^{-3} \cdot \mathrm{min}^{-1}\right)\end{array}$ \\
\hline 0 & 9 & $0.996 \pm 0.02$ & $8.1 \pm 0.9$ \\
\hline 5 & 9 & $0.993 \pm 0.04$ & $9.2 \pm 2.0$ \\
\hline
\end{tabular}

concentration (results not shown). A $t$-test (confidence degree: 90\%) shows that the presence of whey protein at $5 \mathrm{~g} \cdot 100 \mathrm{~g}^{-1}$ water did not significantly modify the overall crystallization rate constant $(k)$ (Tab. I) but lowered lactose solubility: $C(t \rightarrow \infty)=25.6 \pm$ $0.3 \mathrm{~g} \cdot 100 \mathrm{~g}^{-1}$ water in pure lactose solution and $C(t \rightarrow \infty)=24.3 \pm 0.2 \mathrm{~g} \cdot 100 \mathrm{~g}^{-1}$ water in the presence of whey protein at $5 \mathrm{~g} \cdot 100 \mathrm{~g}^{-1}$ water. The solubility values determined by refractometry were in accordance with those given by other authors [1]. Few references have been found concerning the calculation of the lactose crystallization rate constant. Indeed, various available values are not easily comparable because of differences either concerning the units used to express concentrations or the hypothesis considered for the equilibrium analysis [12].

\subsection{Crystal growth}

Several studies have demonstrated the suitability of Laser Light Scattering for crystal size distribution (CSD) measurement [8]. Successful applications of this technique, for example, for adipic acid or naphthalene-toluene crystal size analysis, have been reported in the literature $[8,13]$. Figure 4 shows the evolution of CSD with time during non-seeded lactose crystallization from pure supersaturated solution at $30{ }^{\circ} \mathrm{C}$ (initial lactose concentration of $70 \mathrm{~g} \cdot 100 \mathrm{~g}^{-1}$ water). The shift of CSD reflects lactose crystal size increase. In that study, the evolution of the CSD over time was expressed as the variation of the parameter mode (size value corresponding to the maximum of the curve) of the mass particle size distribution. The parameter mode of the mass particle size distribution is easy to obtain and can be considered as a good indicator for a rapid characterization of a lognormal CSD (Fig. 4). Additionally, compared with mean diameters such as $\mathrm{d}_{4,3}$ (the average volume-weighted diameter) or $\mathrm{d}_{3,2}$ (the average volume-surface diameter), the 


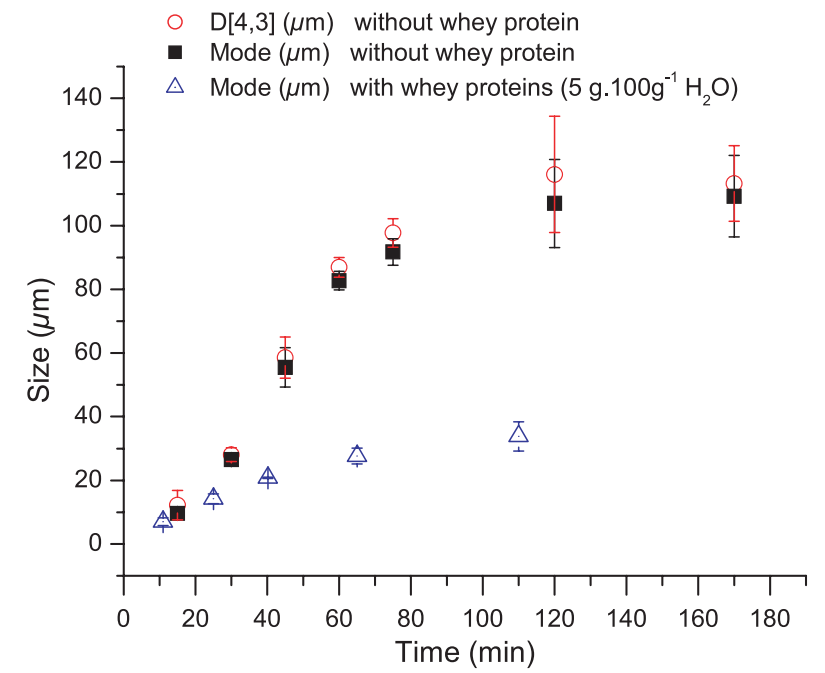

Figure 5. Crystal size versus time during non-seeded crystallization process (initial lactose concentration of $70 \mathrm{~g} \cdot 100 \mathrm{~g}^{-1}$ water). $\mathrm{D}_{4,3}(\mu \mathrm{m})(\mathrm{O})$ and mode $(\mu \mathrm{m})(\boldsymbol{\square})$ versus time for pure lactose supersaturated solution. Mode $(\mu \mathrm{m})$ versus time $(\triangle)$ for lactose supersaturated solution containing whey protein at $5 \mathrm{~g} \cdot 100 \mathrm{~g}^{-1}$ water. Error bars represent standard deviation from three triplicates. mode values are scarcely affected by the accidental presence of very small particles, formed by breakage during suspension circulation in the analyzer, and very big particles such as air bubbles. Nevertheless, in the absence of these particles, evolution of $\mathrm{d}_{4,3}$ and evolution of mode are very similar (Fig. 5). The crystallization of non-seeded lactose supersaturated solutions $\left(70 \mathrm{~g} \cdot 100 \mathrm{~g}^{-1}\right.$ water) with and without whey proteins $\left(5 \mathrm{~g} \cdot 100 \mathrm{~g}^{-1}\right.$ water), were studied in terms of size evolution (Fig. 5). The presence of whey protein at $5 \mathrm{~g} \cdot 100 \mathrm{~g}^{-1}$ water significantly lowered the final size of lactose crystals, i.e. $\sim 30 \mu \mathrm{m}$ against $\sim 105 \mu \mathrm{m}$ in the absence of proteins. The fact that the crystallization rate constant is not modified in the presence of proteins indicates the formation of the same crystal mass of crystals but with a higher number of smaller crystal units. This phenomenon can be explained by the hydrophilic character of whey proteins and their ability to bind water. It is also probable that whey proteins in solution constitute local lactose supersaturation spots, creating favorable conditions for nucleation.

\section{CONCLUSION}

Refractometry and laser light scattering were used to calculate the overall crystalli- zation rate constant and to measure crystal size over time, respectively. These two simple methods were successfully applied to studying lactose crystallization from supersaturated solution with and without whey protein in pure water solution. An ongoing study aimed to use these methodologies to determine how the lactose crystallization rate and crystal size are affected by various components in a more complex mineral environment such as that occurring in industrial acid whey preparations.

Acknowledgements: We acknowledge the food ingredient manufacturer Euroserum, and its R\&D and Quality staff, D. Naegele, P. Vareille and J.P. Humbert for financial support and fruitful discussions. We also thank C. Lopez for her scientific contribution concerning laser light scattering and particle analysis, A. Dolivet for her technical support, M.H. Famelart for helpful scientific discussions and M. Manso for reading and correcting the manuscript.

\section{REFERENCES}

[1] Arellano M.P., Aguilera J.M., Bouchon P., Development of a digital video-microscopy technique to study lactose crystallisation kinetics in situ, Carbohyd. Res. 339 (2004) 2721-2730. 
[2] Barghava A., Jelen P., Lactose solubility an crystal growth as affected by mineral impurities, J. Food Sci. 61 (1996) 180-184.

[3] Bushill J.H., Wright W.B., Fuller C.H.F., Bell A.V., The crystallisation of lactose with particular reference to its occurrence in milk powder, J. Sci. Food Agric. 16 (1965) 622628 .

[4] Garnier S., Petit S., Coquerel G., Influence of supersaturation and structurally related additives on the crystal growth of $\alpha$-lactose monohydrate, J. Cryst. Growth 234 (2002) 207219.

[5] Garside J., Gibilaro L.G., Tavare N.S., Evaluation of crystal growth kinetics from a desupersaturation curve using initial derivatives, Chem. Eng. Sci. 37 (1982) 1625-1628.

[6] Hartel R.W., Shastry A.V., Sugar crystallization in food products, Crit. Rev. Food Sci. Nutr. 1 (1991) 49-112.

[7] Hodges G.E., Lowe E.K., Paterson A.H.J., A mathematical model for lactose dissolution, Chem. Eng. J. 53 (1993) B25-B33.
[8] Monnier O., Fevotte G., Hoff C., Klein J.P., Model identification of batch cooling crystallizations through calorimetry and image analysis, Chem. Eng. Sci. 52 (1997) 11251139.

[9] Raghavan S.L., Ristic R.I., Sheen D.B., Sherwood J.N., The bulk crystallization of $\alpha$-lactose monohydrate from aqueous solution, J. Pharm. Sci. 90 (2001) 823-832.

[10] Roetman K., Methods for the quantitative determination of crystalline lactose in milk products, Neth. Milk Dairy J. 35 (1981) 1-52.

[11] Shi Y., Liang B., Hartel R.W., Crystallization kinetics of alpha-lactose monohydrate in a continuous cooling crystallizer, J. Food Sci. 55 (1990) 817-820.

[12] Smart J.B., Effect of whey components on the rate of crystallization and solubility of $\alpha$-lactose monohydrate, N.Z. J. Dairy Sci. Technol. 23 (1988) 275-289.

[13] Witkowski W.R., Miller S.M., Rawlings J.B., Light-scattering measurements to estimate kinetic parameters of crystallization, Amer. Chem. Soc. (1990) 102-114. 